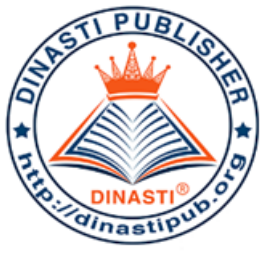

\title{
CONTRIBUTION OF PERSONALITY, AND LEADERSHIP TO ORGANIZATIONAL COMMITMENT OF THE UNIVERSITY OF MH.THAMRIN JAKARTA
}

Mansur

${ }^{1)}$ University Students of the University of Mh.Thamrin Jakarta

\begin{tabular}{|c|l|}
\hline $\begin{array}{c}\text { ARTICLE INFORMATION } \\
\text { Received: } 7 \text { August } 2020 \\
\text { Revised: } 30 \text { August } 2020 \\
\text { Issued: 24 October } 2020\end{array}$ & $\begin{array}{l}\text { Abstract: This study aims to determine the } \\
\text { magnitude of the contribution of personality and } \\
\text { leadership to the organizational commitment of } \\
\text { lecturers. This research method is survey } \\
\text { research. The subjects of this study were } 80 \\
\text { lecturers randomly taken at MH. Thamrin } \\
\text { UniversityJakarta.Data were collected using a } \\
\text { questionnaire instrument using a Likert scale. The } \\
\text { validity of the data is obtained by testing the } \\
\text { validity and reliability; all data have a normal } \\
\text { distribution. The results showed that personality } \\
\text { contributed significantly to the organizational } \\
\text { commitment of lecturers. Likewise, leadership } \\
\text { provides a contribution significant to the } \\
\text { organizational commitment of lecturers. The } \\
\text { coefficient of determinationis personality and } \\
\text { leadership that has a moderate relationship to the } \\
\text { organizational commitment of lecturers. } \\
\text { Keywords: } \\
\text { Organizational Commitment }\end{array}$ \\
\hline
\end{tabular}

\section{INTRODUCTION}

The University of MH Thamrin is one of the Private Universities in the Special Capital Region of Jakarta that has been well accredited, having lecturers still need to consistently carry out its main tasks. Lecturers are professional educators with the main task of transforming, developing, and disseminating science, technology, and art through education, research, and community service (Law No. 14 of 2005 concerning Teachers and Lecturers, Article 1). This requires a good personality to support organizational activities. According to Purba \& Seniati (2004: 105) state that Indonesia 
is a country that has a high collectivity where the interests of the group are above the interests of individuals, so it can be said that the teamwork system develops well in Indonesia.

Besides that, leadership style is needed to support commitment in an organization. Lecturers who are committed in an institution will show good attitudes and behaviors towards their institutions, lecturers will have a soul to defend their organization, try to improve their achievements, and have a certain confidence to help realize organizational goals. Lecturers who have high organizational commitment will prioritize the interests of the organization rather than personal interests and will make their organization a better direction in the future.

Lecturers who are committed to the organization will show attitudes and behaviors positive towards the institution, and have a certain confidence to help realize the goals of the organization (Aisyah, Kamizi, \&Savitri, 2014). Luthan (2006: 249) states that organizational commitment includes, namely: (1) a strong desire to remain as a particular member, (2) a desire to do well according to the wishes of the organization, and (3) certain beliefs, accepting the value of organizational goals. Setyadi\&Sriekaningsih (2015: 211) state that organizational commitment is a situation where a lecturer chooses a particular organization and also the purpose and desire to maintain membership in the organization.

In professional organizations lecturers are professionals who deal with students, the lecturers carry out their duties as educators able to carry out their policies with specific goals and have a strong commitment to the institution. Dessler (2000: 319) states that organizational commitment is a relative strength of an identifiable individual of his organization, which can be seen from three factors, namely: (1) strong trust and acceptance of organizational goals and values, (2) willingness to work for organizational interests, and (3) a strong desire to maintain as a member of the organization.

Mowday (in Aisha, 2014: 45) states that organizational commitment is built when each individual develops three interrelated attitudes towards the organization, namely: (1) identification (identification), namely understanding or appreciation of organizational goals, (2) involvement (involvement) that feeling of being involved in an occupation or a feeling that the work is fun, and (3) Loyalty (loyalty) the sense that the organization is working for. Lecturers who are committed to their institutions will show good attitudes and behaviors towards their institutions, lecturers will have a soul to 
defend their organization, try to improve their achievements, and have a certain confidence to help realize organizational goals. Lecturers who have high organizational commitment will prioritize the interests of the organization rather than personal interests and will make maximum efforts to make the organization better.

Organizational commitment is one of the factors that cause the desire to move. However, empirical evidence still presents different conclusions about the effect of organizational commitment on employee turnover intentions. For example, Hackett (1994) found that organizational commitment put forward by Allen \& Meyer (1990) negatively affected the desire to move. But Meyer's study (1993) concluded that only affective and normative commitment negatively influences the desire to move. Meanwhile, continuance commitment does not significantly influence the employee'sintention.

According Kartini (2005: 7) personality is an important thing from a lecturer because personality can reflect how the lecturer behaves in carrying out their duties. Feist (2010) states that personality is a dynamic and organized characteristic of an individual that is able to influencehis or her cognition, motivation, and behavior. Personality is unique and consistent so that it can be used to distinguish between individuals with one another. Personality as different thought patterns, emotions, behaviors, and characteristics that determine an individual's style and influence his interactions with the environment (Atkinson, 2005). Rahman's research results (2014) states that differences in personality types can cause differences in lecturer performance. So that personality is a dynamic organization in an individual, from the psychophysical system that determines a response that is unique to the work environment. A good personality type is expected to produce good behavior towards the organization.

Personality is a set of characteristics of a stable tendency, which determines the generality and differences in psychological behavior (thinking, feeling, and movement) of a person for a long time and cannot be understood simply as a result of current biological stress (Alwisol, in Sudjiwati, 2010 ). According to Sudjiwanati (2010) states that the individual's personality is very influential in overcoming the problems faced by the individual himself. Personality as an internal stimulus that is able to provide a different response to the characteristics of a person's behavior. Almost similarly Gibson (1996: 360) states personality is a series of characteristics and stable tendencies that determine commonality or general matters and differences in human behavior. While 
Greenberg and Baron (1997: 109) statesthat personality is related to the unique and relatively stable, behavioral, thought, emotional patterns exhibited by individuals.

According to Kreitner (2008: 463) leadership is the process of influencing a group of people to create their voluntary participation in efforts to achieve organizational goals. Good leadership must give direction to the efforts of all lecturers' work in achieving organizational goals, without good leadership the relationship between individual goals and organizational goals may be weak. According to Yuki (2006: 5) states that leadership is a process of encouraging and helping others to work enthusiastically to achieve goals. Human's factors that link groups and motivate them to achieve the goals of an organization.Leadership is as an influence, art, and a process of influencing people so that they will try to achieve group goals with will and enthusiasm (Bangun, 2012: 338). It is interpreted that leadership is seen as the ability to influence groups in achieving organizational goals.

To achieve the goals of an organization, a leader must have the ability, namely: (1) Integrity includes fairness, honesty, and trustworthiness, (2) Competence, namely administrative, communication, and problem-solving skills with mutual benefit, and (3) Benevolence namely characteristics positive person as a leader to work together and be able to raise one's spirits in achieving organizational goals (Henry, 2004: 139). In contrast, Siagian (2009: 62-63) views leadership is an individual ability to influence others, so that people want to do the will of the leader even though it might not be liked. This means that someone who occupies the position of leader is required to have certain abilities that are not possessed by other human resources in the organization.

Leadership is an important factor in determining individual and group behavior in organizations. Errors in determining leadership style will have an impact on the decreasing effectiveness of lecturers' work if leadership in higher education can manage and assist properly so that lecturers can carry out their tasks such as tri dharma higher education with full responsibility. Leadership is expected to be able to pay attention to the interests and welfare of lecturers so that there are no complaints in carrying out their duties, they must demonstrate their authority so that they can be emulated and obeyed by the lecturers. Establish and at the same time implement the rules of higher education that are logical and systematic, and can be accepted by all parties involved in increasing the effectiveness of duties and obligations. According to John (2008: 159) states that leadership is a process used by someone to influence group members towards the achievement of organizational goals. Ivanceviech (2008: 413) states that leadership is an 
attempt to influence people or individuals (interpersonal) through the communication process to achieve organizational goals.

Therefore this study seeks to determine the influence and magnitude of the contribution of personality, and leadership to the organizational commitment of the university lecturer at MH Thamrin Jakarta.

\section{RESEARCH METHODOLOGY}

This research is survey research. The dependent variable is the organizational commitment of lecturers; the independent variables are personality and leadership. The study was conducted at MH.Thamrin University Jakarta in 2019/2020 school year. Research subjects 80 lecturers were taken randomly, collecting data using a Likert scale. The validity of the data is obtained by testing the validity and reliability. Based on the results of the normality test at the level of $\alpha=0.05$ research subjects that have a normal distribution can be seen in Table 1 .



Picture 1. Research Constellation

Description:

$\mathrm{Y}=$ Commitment of lecturer organization

$\mathrm{X} 1=$ Personality

X2 = Leadership

Test Analysis Requirements

Table. 1 Data Normality Test Results with the help of the SPSSProgram

One-Sample Kolmogorov-Smirnov Test

\begin{tabular}{|ll|r|r|r|}
\hline & $\begin{array}{c}\text { Organizational } \\
\text { CommitmentLect } \\
\text { urer }\end{array}$ & Personality & \multicolumn{1}{c|}{ Leadership } \\
\hline $\mathrm{N}$ & Mean & 80 & 80 & 80 \\
Normal Parameters, & 78.3082 & 40.0381 & 48.1903 \\
& Std. Deviation & 5.703175 .20497 & & 5.34079 \\
Most Extreme Differences & Absolute & .085 .058 & & .087 \\
& Positive & .078 .072 & & .087 \\
& Negative & -.088 & -.073 & -.081 \\
Test Statistic & & .069 .074 & .095
\end{tabular}


Asymp. Sig. (2-tailed) $.059^{\mathrm{c}}$ $.204^{\mathrm{c}, \mathrm{d}}$ $.178^{\mathrm{c}}$

In Asymp.Sig (2 tailed) lecturer organizational commitment (Y) of 0.059, personality $\left(\mathrm{X}_{1}\right)$ of 0.204 and leadership $\left(\mathrm{X}_{2}\right)$ of 0.178 .

Criteria for testing the value of asymp sig $>$ at $\alpha=0.05$ means that all variables have normal distribution data.

Table 2. Linearity Test of Personality Regression Equations Against Organizational Commitment ofLecturers

\begin{tabular}{|c|c|c|c|c|c|c|c|}
\hline \multicolumn{8}{|c|}{ ANOVA table } \\
\hline & & & $\begin{array}{l}\text { Sum of } \\
\text { Squares }\end{array}$ & Df & $\begin{array}{l}\text { Mean } \\
\text { Square }\end{array}$ & $F$ & Sig. \\
\hline \multirow{5}{*}{$\begin{array}{l}\text { Lecturer } \\
\text { Organizational } \\
\text { Commitment } \\
* \text { Personality }\end{array}$} & Between & (Combined) & 1637,609 & 20 & 72,417 & 2,540 & .002 \\
\hline & Groups & Linearity & 873,462 & 1 & 873,462 & 35,196 & .000 \\
\hline & & $\begin{array}{l}\text { Deviation from } \\
\text { Linearity }\end{array}$ & 584,192 & 19 & $27,9130 \alpha$ & $\begin{array}{r}1,7508= \\
=\end{array}$ & $\begin{array}{r}.3920 \\
\alpha 0 \alpha\end{array}$ \\
\hline & Within G & & 1637,819 & 57 & 29,483 & & \\
\hline & Total & & 3054,902 & 77 & & & \\
\hline
\end{tabular}

Criteria for testing the value of sig $0,392>=0,05$ means the equation of personality regression of the organizational commitment of lecturers is linear.

Table 3. Linearity Test of Leadership Regression Equations Against Lecturer Organizations

\begin{tabular}{|c|c|c|c|c|c|c|c|}
\hline \multicolumn{8}{|c|}{ ANOVATable } \\
\hline & & & $\begin{array}{l}\text { Sum of } \\
\text { Squares }\end{array}$ & Df & $\begin{array}{l}\text { Mean } \\
\text { Square }\end{array}$ & $\mathrm{F}$ & Sig. \\
\hline \multirow{5}{*}{$\begin{array}{l}\text { * Leadership } \\
\text { Lecturer } \\
\text { Organizational } \\
\text { Commitment }\end{array}$} & $\begin{array}{l}\text { Between } \\
\text { Groups }\end{array}$ & $\begin{array}{l}1164,90150,195.0 \\
82\end{array}$ & & 20 & & 1,664 & $\begin{array}{l}\text { (Com } \\
\text { bined }\end{array}$ \\
\hline & & Linearity & $\begin{array}{r}754,147 \\
20,092.000\end{array}$ & 1 & & & $\begin{array}{r}754,1 \\
47\end{array}$ \\
\hline & & $\begin{array}{l}\text { Deviation from } \\
\text { Linearity }\end{array}$ & $\begin{array}{r}19,907.514 \\
.907 \\
\end{array}$ & 19 & & & $\begin{array}{r}360,7 \\
80 \\
\end{array}$ \\
\hline & \multicolumn{2}{|c|}{ Within Groups } & 2083.905 & 58 & 35176 & & \\
\hline & \multicolumn{2}{|l|}{ Total } & 3172.064 & 78 & & & \\
\hline
\end{tabular}

value test criteria $\operatorname{sig} 0.907>$ at $\alpha=0.05$ means that the leadership regression equation for the organizational commitment of lecturers is linear. 


\section{Results}

Table 4. Multiple Regression Coefficients and the significance level of

\begin{tabular}{|c|c|c|c|c|c|c|}
\hline \multicolumn{7}{|c|}{ Coefficients } \\
\hline \multirow{2}{*}{\multicolumn{2}{|c|}{ Model }} & \multicolumn{2}{|c|}{ Unstandardized coefficients } & $\begin{array}{l}\text { Standardized } \\
\text { Coefficients }\end{array}$ & & \\
\hline & & B & Std. Error & Beta & $\mathrm{t}$ & Sig. \\
\hline & (Constant) & 41,076 & 5,091 & & 8,017 & .000 \\
\hline & Personality & .528 & .185 & .483 & 3,824 & .002 \\
\hline & Leadership & .391 & .152 & .276 & 2,417 & .017 \\
\hline
\end{tabular}

Personality is influentialsignificantly to the organizational commitment lecturers.

Testing criteria: value $_{\mathrm{t}}=3.824>\operatorname{sig}=0.002$ at $\alpha=0: 05$.

Leadership has a significant effect on the organizational commitment of lecturers.

Testing criteria: value $_{\mathrm{t}}=2.417>\mathrm{sig}=0.017$ at $\alpha=0: 05$.

Table 5. Multiple Linear Regression Coefficients Testing

\begin{tabular}{|ll|r|r|r|r|r|}
\hline Model & & Sum of Squares & Df & Mean Square & F & Sig. \\
\hline 1 & Regression & 1019,318 & 2 & 510,953 & 21,087 & \\
& Residual & 2106,517 & 75 & 27,817 & & \\
& Total & 3054,259 & 77 & & & \\
& & & & & \\
\hline
\end{tabular}

Personality and leadership together have a significant influence on the organizational commitment of lecturers.

Test criteria: Fvalue $_{\text {Calculated }}=21.087>$ sig value $=0.000$ at $\alpha=0.05$.

Table 6. Coefficient of Determination

\begin{tabular}{|l|r|c|c|r|}
\hline Model & $\mathrm{R}$ & R Square & $\begin{array}{c}\text { Adjusted R } \\
\text { Square }\end{array}$ & Std. Error of the Estimate \\
\hline 1 & $.853^{\mathrm{A}}$ & .3475 .02906 & & .647 \\
\hline
\end{tabular}

The coefficient of determination ( $\mathrm{R})^{2}$ amounted to $64.7 \%$ means that the personality and leadership have a relationship that was on organizational commitment of lecturers, while the remaining $35.3 \%(100 \%-64,7 \%)$ were not analyzed in this study.

The results of the analysis of each indicator in the research instrument are seen in the matrix as follows:

Table 7. Analysis of each indicator in the Research Instrument 


\begin{tabular}{|c|c|c|c|c|}
\hline No & Indicator & $\begin{array}{c}\text { Number of } \\
\text { Points }\end{array}$ & Average & Status \\
\hline \multicolumn{5}{|c|}{ Score Questionnaire Personality } \\
\hline 1 & Emotional tendency & 9 & 4.07 & Always \\
\hline 2 & Use of cognitive abilities & 4 & 3.90 & Frequent \\
\hline 3 & Behavioral propensity & 8 & 3.81 & Often \\
\hline 4 & Adaptability & 5 & 587 & Often \\
\hline 5 & Use of conscience & 3 & 3.99 & Frequently \\
\hline Num & er of questionnaire items & 30 & & \\
\hline \multicolumn{5}{|c|}{ Leadership Questionnaire Score } \\
\hline 1 & Decision-making ability & 6 & 3.62 & Frequent \\
\hline 2 & $\begin{array}{l}\text { Implementation of Coaching, } \\
\text { Supervision and Control }\end{array}$ & 5 & 3,16 & Often \\
\hline 3 & Carry out Work Distribution & 6 & 4.32 & Always \\
\hline 4 & Effectiveness in communication & 4 & 4.59 & Always \\
\hline 5 & Give directions and commands & 5 & 4.19 & Always \\
\hline 6 & Be a role model & 4 & 2.65 & Sometimes \\
\hline Num & er of questionnaire items & 30 & & \\
\hline \multicolumn{5}{|c|}{ Score Questionnaire Organizational Commitment } \\
\hline 1 & $\begin{array}{l}\text { Understanding and appreciation of } \\
\text { organizational goals }\end{array}$ & 12 & 4.25 & Always \\
\hline 2 & $\begin{array}{l}\text { Feelings of involvement in the } \\
\text { organization }\end{array}$ & 12 & 4.23 & Always \\
\hline 3 & Level of work loyalty & 6 & 4.21 & Always \\
\hline Num & er of items questionnaire & 30 & & \\
\hline
\end{tabular}

The results of this analysis showed that the main contribution comes from the lecturer's personality-forming indicator oftendency the emotional and the use of conscience. In the leadership variable, the respondents assume that the leadership contribution is mainly formed from indicators: 1) effectiveness in communication, 2) carrying out the division of labor, and 3) giving direction and order. While the results of the analysis of the scores of each indicator on the organizational commitment variable obtained information that the three indicator variables have a mean score close to each other at the same level that is very high range. In terms of the value of the contribution of successive indicators: (1) understanding and understanding of organizational goals (4.25) are very high, (2) feelings of involvement in the organization (4.23) are very high, and $(3)$ the level of work loyalty $(4,21)$ that is very high. This shows that the three 
indicators together contribute to the formation of high organizational commitment of lecturers.

\section{DISCUSSION}

\section{Personality Gives a Significant Contribution to Organizational Commitment of}

\section{Lecturers}

According to the results of the study, referring to the opinion of Gibson (1996: 360) states that personality is a series of characteristics and stable tendencies to determine commonality or general matters and differences in human behavior. However, Greenberg and Baron (1997: 109) statethat personality is related to the behavior, thoughts, emotional unique, and relatively stable shown by individuals. So the opinion can be interpreted that a good personality can produce good behavior towards commitment in the organization. Regarding the opinion of Setyadi\&Sriekaningsih (2015: 211) states that organizational commitment is where a lecturer chooses an organization to have the desire and purpose to maintain its membership. So it can be said that if the lecturer has a good personality, then the lecturer commits to carry out his duties properly so that the institution can be more advanced.

\section{Leadership Gives Significant Contributions to the Organizational Commitment of Lecturers}

In accordance with the results of the study, referring to the opinion of Kreitner (2008: 463) states that leadership is a process of influencing a group of people to create their voluntary participation in efforts to achieve organizational goals. Then by referring to the opinion of Goetsch and Davis (2010: 178) state that leadership is the ability to inspire others, according to the wishes and voluntary commitment to achieve organizational goals. In addition, Dessler (2000: 319)states that organizational commitment as a relative strength of identificationindividual of the organization, including trust in the goals of organizational values, willingness to pursue organizational interests, and a strong desire to maintain as a member of the organization. If the leader implements good leadership, then the team commits and strives maximally so that the organization gets better.

3. Personality and Leadership Together Make Significant Contributions to the Organizational Commitment of Lecturers. 
In accordance with the results of the study, referring to the opinion of Sudjiwanati (2010) states that the personality of the individual is very influential in overcoming the problems encountered. Concerning the opinion of Greenberg and Baron (1997: 109) statesthat personality is related to the behavior, thoughts, and relative stability shown by individuals in an organization. When associated with leadership According to John (2008: 159) states that leadership is a process used by someone to influence group members towards the achievement of organizational goals. Then by referring to the opinion of Ivanceviech (2008: 413) states that leadership is an attempt to influence people or individuals (interpersonal) through the communication process to achieve organizational goals.

The opinion of Kamizi\&Savitri (2014) states that lecturers who are committed to the organization will show good attitudes and behaviors towards their institutions, and have a certain confidence to help realize the goals of the organization. Luthan (2006: 249) states that organizational commitment, including a strong desire to remain as a member of the organization, a desire to do well in accordance with the wishes of the organization, and confidence can accept the value of organizational goals. If the lecturer has a good personality and the leader of the application of good leadership, then the lecturer still commits the organization to advance the institution.

\section{Conclusions}

Personality contributes significantly to the organizational commitment of lecturers. Then leadership contributes significantly to the organizational commitment of lecturers. Furthermore, personality and leadership together contribute significantly to the organizational commitment of lecturers.

\section{REFERENCES}

Allen, NJ, \& Meyer, JP 1990.The measurement and antecedents of affective, continuance, and normative commitment to organization. Journal of occupational psychology, 63, 1990

Atkinson, et al. 2005.Introduction to Psychology First Edition. Jakarta: Erlangga Publisher.

Wake up, Wilson. 2012. HumanManagement Resource. Jakarta: Erlangga.

Dessler, G. 2000. Human Resource Management 8th edition, New Jersey: Prentice Hall, Inc. 
Feist, J. \&. Feist, GJ 2010.Theories of personality. Jakarta: SalembaHumanika.

Gibson, James L., Ivancevich, John M., 1996. Donnelley, Jr. James H. Indonesian Edition Organization. Jakarta: Binarupa script.

Rahman, G. A. 2014. The Effect of Organizational Design and Personality Type on Employee Job Stress at Manado Religious Training Centers. Manado: EMBA Journal ISSN2303-1174, 2014.

Greenberg, Jerald \& Baron, Robert., 1997. Behavior In Organizations. United of America: Sixth edition by Prentice Hall Inc.

Henry Lane, W et al. 2004. The Blackwell Handbook of Global Management. Victoria: Blackwell Publishing.

Ivancevich, John M., and Matteson, Michael T. 2008.Organizational Behavior and Management. Singapore: Irwin McGraw Hill.

John, MC, and John, WT 2003.Leadership style, school climate, and the institutional commitment of teacher. Dissertation, Doctoral in Seventh-DayAdventist secondary Schools, In Philippines.

Kartono, Kartini. 2005. Personality Theory. Jakarta: MandarMaju. Klang, A. 2010.Thesis: The Relationship Between Personality and Job Performance in Sales. Stockholm University, Department of Psychology.

Kreitner, Robert and kinicki, Angelo. 2008. Organization behavior. Singapore: McGraw-Hill.

Luthans, Fred. 2006. Organizational Behavior translation VivinAndhika et al. Yogyakarta: Andi.

Newstrom, John W. 2008. Organizational Behavior.Singapore, McGraw-Hill.

Purba, Debora Eflina\&Seniati, Ali N L. 2004. Effect of personality and organizational commitment on organizational citizenship behavior. Makara Journal Vol. 8 No. December 3, 2004.

Setyadi, Djoko and Sriekaningsih, Ana. 2015. The Effect of competence and motivation and cultural organization towards organizational commitment and performance on state University Lecturers in East Kalimantan Indonesia. European Journal of Business and Management, Vol.7 No.17, 2015.

SitiAisyah, Karmizi, and Savitri.The Effect of Good Governance, Leadership Style, Organizational Commitment and Organizational Culture on Local Government Performance.JOM FEKON Vol.1 No.2. 2014.

Siagian, Sondang. 2009. Tips for Increasing Work Productivity. Jakarta: RinekaCipta.

Sudjiwanati. (2010). The influence of big five personality types on the transformational leadership style of employees of PT. ArtaBogaCemerlang Surabaya. Journal of applicationsManagement, Vol 8, No.3 August 2010. 
Law No. 14 of 2005 concerning Teachers and Lecturers.

Yuki, Gary. 2006. Leadership in Organization, sixth Edition, Pearson Prentice Hall. 